\title{
Editorial
}

\section{A Body Response to the Urban Middle East}

The urban Middle East is an archaeological and historical fact. Modernity has necessitated enlargement of these urban sites and has created many urban hubs, as well as different residential and professional allocations around previous sites. It has created new centres, yet it has also destroyed - through contemporary architecture and city planning, not to mention war and bombardment - some of its famous points of interest.

What has been the role of anthropology in studying the urban Middle East, and are we paying enough attention to this topic? It was with the aim of answering these questions and drawing more attention to this subject that we launched this issue. In these pages we present some of the most recent works on this topic, taking into consideration the prolific interest in urban anthropology in general and the acute interest in daily life in urban areas due to the recent dissatisfaction of the people who live in the region.

Özgür Türesay's article pays historical attention to change and the way that the ancient city of Istanbul became modernised through a different form of rational city planning. Türesay examines the works of an Ottoman journalist, Ebüzziya Tevfik, who published over two dozen articles following the Young Turk Revolution of 1908 that reflect the connections Tevfik made between urbanism and civilisation. Hayder Al-Mohammad's article on Basra is about a city affected by war, a city in utter disorder that is looking at tribal support, instead of legal systems or insurance companies, as a way to survive. This critical article shows how the everyday life of urban Middle Easterners does not centre on topics that are important to the international media. People's worries are not about the difference between Shi'a and Sunni, sectarian violence or civil war; rather, their concerns are focused on surviving threats from aggressors of all kinds, finding a doctor who could save the life of their child and living each day in the hope that a better future awaits themselves and their children. While these people have been substantially affected by the invasion of 2003, their pressing concern is to try to make their daily lives continue in an acceptable way, using any kind of support, traditional or modern. 
The theme of people's everyday lives interests other authors in what is closest to every human being: his or her body. This is not a response to body studies in anthropology, which has become central to the study of urban life. Rather, it reflects the importance that Middle Easterners attach to keeping their bodies healthy as their last resort in situations of abrupt change. This interest in the body covers both traditional and modern medicine, the image of one's body in the public space and tacit competition with one's peers on issues of beauty and wealth. In the article on Saudi Arabia, contributed by six medical professionals, we see the difference between the perception, diagnosis and healing of illnesses and their symptoms as perceived by both patients and health care providers. The authors find it alarming that there should be such discord between patients and health care workers. Modernity - and in this regard the medical profession - has brought about a divergence of views that stems in part, the article concludes, from cultural and educational differences.

Sara Lenehan's article on rhinoplasty shows how the Iranian people - deep into an Islamic Revolution with media attention that has highlighted raised fists, black veils and turbaned politicians - are concerned with beauty and identity. How could a region in such upheaval embrace these seemingly superfluous matters? The daily activities of most Iranians are centred on family life, with an emphasis placed on comparisons with close kin and friends. While global influences are acknowledged, it is more a matter of prestige, image consciousness and class awareness on the local scale that informs the present circumstances. In an arena filled with tensions, the use of cosmetic surgery to reshape one's facial features or body shape has become accepted among various classes and ideological proponents, perhaps as a source of personal affirmation and, Lenehan suggests, as a way of confirming or contesting identities and relationships with individuals and authorities.

How does one keep and recreate the kin who provide the most important context for creating a sense of self and well-being? For many, this is achieved by taking part in traditional ceremonies and by adhering - as well as one possibly can - to established rituals, particularly those related to rites of passage. In her discussion on qalin (bride price) in Uzbekistan, Ziyodakhon Rasulova analyses a custom that, despite criticisms and negative assessments, has managed to survive to the present day. Notwithstanding its focus on economic factors, the practice has a symbolic meaning that might help to guarantee continuation in a relationship.

In all of the contributions to this issue, modernity is present in urban areas, and family life and traditional views are prevalent. This we also see in Nadeem Karkabi's article about European women and Egyptian men making temporal bonds in the margins of society. Using their bodies as instruments, ageing European females, hoping for a new chance at romance, and young Egyptian males, responding to certain views of freedom and also for pecuniary reasons, engage in temporary unions - based on reformulated traditional marriages that are a response to modernity and, further, globalisation. Drawn together 
for different reasons, these couples create a balanced partnership in which each helps to solve the other's problems. In his conclusion, Karkabi suggests that, due to the destruction brought about in mainstream societies by globalisation, cultural reconstructions such as these may emerge from society's margins.

With regard to the subject of daily life in urban areas, our Egyptian colleague Hania Sholkamy was present in Cairo's Tahrir Square in January 2011, and she gives us a brief account of her experiences. This is deeply appreciated by our journal, and we urge our readers to send us their observations and reflections during these important periods of life in the Middle East.

Finally, it is significant that our film review also relates to the body, this closest and last instrument at one's disposal. Due to modern medical interventions, the mutilated bodies of Afghan women no longer signify the end of their lives. One woman declares, 'Grâce à Dieu, j'ai un pied en plastique' (By the grace of God, I have a plastic foot) - as a result of which she can work, run and ride a bicycle. Another woman states, 'Je suis la mère handicapée la plus heureuse' (I am the happiest handicapped mother). By affirming their difference through a body that has been maimed as the result of an imposed war but then 'repaired' through modern medicine, these women have found a voice.

In this issue, we examine aspects of life in the urban Middle East, including the day-to-day concerns of its people and the instrumentality of the body. Very harsh realities are portrayed, and local responses are also presented. The acuteness of the situation is shown through life within one's extended kin and tribe and that which is closest at hand - one's own body. Maintaining health and feeling good about oneself are positive responses to all the tensions and pressures that presently affect everyday life in modern Middle Eastern cities. 